\title{
THE RELATIONSHIP BETWEEN BURNOUT AND ORGANIZATIONAL COMMITMENT AMONG HEALTH SECTOR STAFF IN TURKEY
}

\author{
*Nilay GEMLIK \\ *Fatma Ayanoglu SISMAN \\ **Unsal SIGRI, \\ *Marmara University, TURKEY \\ **Turkish Military Academy, TURKEY
}

\begin{abstract}
In today's chaotic and dynamic era, organizations search and define main trends in business to improve efficiency. Defining the components of organizational behavior and understanding the relationships among these notions has a vital role for the viability of organizations. This study aims to determine the relationship between burnout and organizational commitment among health sector staff in Turkey. In the beginning of this study, the purpose, research question, and the need for the study is given. Then, literature is discussed on burnout and organizational commitment focusing on the relationship between them. An analysis of the data collected by The Maslach Burnout Inventory (MBI) and Allen and Meyer's Organizational Commitment Scale from 459 personnel is researched afterwards. Considering findings, after presenting demographic information of the variables like task position, gender, educational background and age, the reliability and factor analysis tests of the two scales are performed within the study. Then the relationship between the variables is studied with regression analysis. The analysis of the regression test results in this study shows the relationship between burnout and organizational commitment among health sector staff in Turkey. In that respect, present data provide support for the hypothesis that burnout typically has been assumed to be a predictor of organizational commitment.
\end{abstract}

\section{Introduction}

In today's dynamic and chaotic era, management paradigms of organizations are becoming more human-oriented. Organizations need their staff to contribute their creativity, ideas, and opinions to various issues to improve overall production quality in different sectors. In recent years, competition and changes in technology also have affected the health sector seriously. Businesses in this sector want to increase their own competitive levels for their existence and continuity. In this way, they adopt certain policies to obtain qualified personnel more adaptable and skilful to changes.

In that respect, organizational commitment means a cost problem that businesses are likely to be confronted with sooner or later. Moreover, in today's competitive atmosphere, it is an undeniable fact that organizations need workers with high commitment and low burnout levels more than ever before. Since personnel with high organizational commitment levels and with low burnout levels facilitate reaching organizational aims and targets, low rate resignation and absenteeism, high quality service and customer satisfaction are among the most important factors in organizational behavior issues. Researching these two issues is the main purpose of this study. Also, the relationship between burnout and organizational commitment among health sector staff in Turkey will be the main research question of the study.

In order to assure the personnel's commitment to the organization, as many theoretical and empirical studies show, it appears necessary to take into account not only direct factors like answering direct economic expectations, but also indirect factors like improving working conditions, assuring job satisfaction, meeting personal needs, and answering expectations regarding the functioning structure of the organization in order to deal with organizational burnout. Such indirect factors refer to a direct relationship between developing organizational commitment and achieving productivity and personnel whose expectations regarding the organization are fully answered. 


\section{ORGANIZATIONAL BURNOUT}

Burnout has been defined as a specific kind of occupational stress in human service professionals, which results from the demanding and emotionally charged relationships between caregivers and recipients (Maslach and Jackson, 1986).

In recent years, increasing attention has been paid to the phenomenon of burnout, particularly in human services professions. Burnout appears to be a response to interpersonal stressors on the job, in which an overload of contact with people results in changes in attitudes and behaviors toward them. More specifically, burnout has been defined as a syndrome of emotional exhaustion, depersonalization, and a reduced sense of personal accomplishment that can occur among individuals who work with people in some capacity (Maslach and Jackson, 1986, 1984).

As described above, burnout is studied in three different types. "Emotional exhaustion" refers to feelings of being emotionally overextended and drained by one's contact with other people. "Depersonalization" refers to an unfeeling and callous response toward these people, who are usually the recipients of one's service or care. Thirdly, "reduced personal accomplishment" refers to a decline in one's feelings of competence and successful achievement in one's work with people. These three aspects of the burnout syndrome have been the focus of numerous research studies investigating the causes and outcomes of burnout (Maslach and Jackson, 1986).

Health sector staffs generally are considered at high risk of work-related stress, and burnout has been a major concern in the field of occupational health (Shimizu et al., 2003). Health personnel experience considerable stress in their job because they have long working hours, a wide range of tasks, and complicated relationships with patients, their families, doctors, and other coworkers (Maslach et al., 2001).

\section{ORGANIZATIONAL COMMITMENT}

Organizational commitment of the staff has been a commonly studied issue recently. The most commonly used definition of organization commitment belongs to Allen and Meyer (1990), "a psychological state that binds the individual to the organization."

Allen and Meyer, define organizational commitment as a multidimensional construct. Accordingly, there are three different types of organizational commitment: affective, normative, and continuance commitment. Affective commitment is "the employee's emotional attachment to, identification with, and involvement in the organization," whereas normative commitment is defined as a "feeling of obligation to continue employment." Finally, continuance commitment occurs as a result of "an awareness of the costs associated with leaving the organization." Each dimension is thought to contribute to an employee's relationship with the organization, has implications for his/her continuing membership, and may be affected by different antecedents or may have different consequences (Meyer and Allen, 1991).

Organizational commitment refers to employee identification with, and involvement in, a particular organization (Mowday, Steers and Porter, 1979). Higher levels of commitment are reflected in lower rates of turnover (Steers, 1977), and also are believed to be related to enhanced productivity and better delivery of services. It seems reasonable to postulate that the experience of burnout would lead employees to be less committed to the organization, and thus more likely to quit their jobs. If employees are feeling emotionally exhausted by their work, are developing depersonalized views of the people they serve, and are feeling that they are not accomplishing much, then they would probably become less enthusiastic and accepting of the organization's goals, less dedicated to achieving them, and more prone to withdrawing from work (both psychologically and physically).

Thus, organizational commitment may be the mediating variable in the link that has been found between burnout and both turnover and job withdrawal (Jackson et al., 1986). Similarly, burnout may be an important mediating variable between interpersonal aspects of the work environment and organizational commitment. It could be argued that burnout is the key factor here, in that it is a likely response to interpersonal stressors and conflict, which then instigates withdrawal from the organization. 


\section{Relationship Between Organizational Commitment and Burnout}

In a previous study, it was found that undergraduate personnel have shown a greater organizational commitment than university graduate personnel (Ceylan, 2002: 97).

Burnout, also called "work stress," including three sub-dimensions of emotional exhaustion, depersonalization, and reduced personal accomplishment, is caused mainly by the face-to-face nature of the work (see Sunter, et. al., 1996, and Sucuoglu \& Kuloglu, 1996).

A previous study that considered occupational differences found that there is no difference between nurses and midwives in scope of the sub-dimensions of organizational burnout. The same study also pointed out the result that younger workers experience emotional exhaustion and depersonalization at a higher level than others (Aras, 2006: 82).

In literature, it is found that personnel with high educational backgrounds experience higher burnout than others. This result reveals that highly educated personnel are having more responsibilities and higher expectations when compared to others (Maslach and Jackson, 1981). One of the findings assume that the higher work experience duration, the less organizational burnout, depersonalization and personal accomplishment by means of the experiences gained (Sarikaya, 2007: 118).

\section{Methodology}

\section{Sample and Research Sites}

This study is performed with the health sector staff of two Medicine Faculty Hospitals in Istanbul in June-July 2008, including doctors, nurses, and other positions (managers and employees). One of the hospitals has a total of 1,260 personnel, including 550 doctors, 230 nurses, and 460 managers and others, while the other hospital has a total of 697 personnel including 116 doctors, 92 nurses, and 489 managers and others. Out of 1957 total hospital personnel $23 \%$ took part in the survey. The sample of the study is composed of 80 doctors, 160 nurses, 17 managers, and 10 others from the first hospital and 36 doctors, 133 nurses, 15 managers, and 8 others from the other.

\section{Measures}

The first part of the questionnaire includes demographic information of such variables as task position, gender, educational background, and age. This sociodemographic part of the scale is designed with the help of academicians from business and statistics that had the last version after being applied to 10 persons. Following, the Maslach Burnout Inventory (22 items) and Allen and Meyer's Organizational Commitment Scale are used to collect data.

\section{The Maslach Burnout Inventory}

The validity and reliability tests of the Turkish version of Maslach's Burnout Scale (5-item Likert scale) were performed by Ergin (1992) and Cam (1992). This scale includes 22 questions and three dimensions, with emotional exhaustion and depersonalization categories having negative statements and the reduced personal accomplishment category having positive statements. Therefore, when emotional exhaustion and depersonalization scores are getting higher and reduced personal accomplishment scores are getting lower, it is believed that burnout is increasing. Because some questions $(4,5,7,12,18,19$, and 21$)$ are reverse, they also are processed with a reverse methodology.

High levels of emotional exhaustion and depersonalization remind us of the signs of organizational burnout. The emotional exhaustion subscale reveals the burnout mood with the heavy job burdens, while the depersonalization subscale represents the disregardful behavior toward people to whom is served. Finally, the reduced personal accomplishment subscale reveals the mood of handling over situations with the help of personal success (Ciper, 2006: 63). 
With the reliability analysis of the Burnout Scale, the Cronbach alpha score of the scale is found as 0.8571 , including all questions, and subsequently it is found as 0.8634 excluding the fourth statement of "I immediately understand what people feel because of my job," which has a decreasing factor on the scale (s.d. 231, $\mathrm{p}=0,000$ ).

\section{Allen \& Meyer's Organizational Commitment Scale}

The Turkish version of an 18-item Likert scale (Mine, 2006: 73) of Allen \& Meyer's Organizational Commitment Scale (1990) is used in this study, having subfactors of affective, continuance, and normative commitment. Because statements 7, 13, and 15 are reverse questions, they are processed in reverse methodology.

With the reliability analysis of the Organizational Commitment Scale, the Cronbach alpha score of the scale is found as 0.8068 , including all questions and subsequently found as 0.8191 excluding the seventh statement of "I work in this institution because of my obligations instead of my own will," which has a decreasing factor on the scale.

\section{Findings}

\section{Demographic Findings}

Women comprise $60.6 \%$ of the sample size. The sample is formed by doctors, nurses, managers, and other positions. Doctors comprise $27.8 \%$ of the sample while nurses comprise $60.8 \%$ and managers $5.5 \%$. Of the sample, $55.7 \%$ are university graduates and $57.9 \%$ are married. The average age of the participants is 33 and job experience duration is seven years in this study. (Table 1)

Table 1: Frequencies of Gender, Position, and Educational Background

\begin{tabular}{|l|l|l|}
\hline & Dispersion of requencies & Dispersion of Percentage \\
\hline Gender & & \\
\hline Woman & 278 & 60.6 \\
\hline Man & 181 & 39.4 \\
\hline Total & 459 & $\mathbf{1 0 0 . 0}$ \\
\hline & & \\
\hline Positions & & \\
\hline Doctor & 116 & 25.3 \\
\hline Nurse & 293 & 63.8 \\
\hline Manager & 32 & 7.0 \\
\hline Others & 18 & 3.9 \\
\hline Total & 459 & $\mathbf{1 0 0 . 0}$ \\
\hline & & \\
\hline Educational Background & & \\
\hline Primary & 12 & 2.6 \\
\hline High School & 73 & 15.9 \\
\hline College & 62 & 13.5 \\
\hline University & 256 & 55.8 \\
\hline Master's degree & 41 & 8.9 \\
\hline Doctoral & 15 & 3.3 \\
\hline Total & 459 & $\mathbf{1 0 0 . 0}$ \\
\hline & & \\
\hline Marriage & & 64.9 \\
\hline Married & 298 & 35.1 \\
\hline Single & 161 & $\mathbf{1 0 0 . 0}$ \\
\hline Total & 459 & \\
\hline & & \\
\hline
\end{tabular}


Table 2: The Age and Job Experiences of the Participants.

\begin{tabular}{|l|l|l|l|l|l|}
\hline & N & $\begin{array}{l}\text { Smallest } \\
\text { Value }\end{array}$ & $\begin{array}{l}\text { Biggest } \\
\text { Value }\end{array}$ & Mean & $\begin{array}{l}\text { Std. } \\
\text { Deviance }\end{array}$ \\
\hline Age & & & & & \\
\hline Responsive & 457 & 19 & 57 & 33 & 6.2 \\
\hline Irresponsive & 2 & & & & \\
\hline Total & $\mathbf{4 5 9}$ & & & & \\
\hline Duration of Job Experience & & & & & \\
\hline Responsive & 457 & 1 & 28 & 7.05 & 6.13 \\
\hline Irresponsive & 2 & & & & \\
\hline Total & $\mathbf{4 5 9}$ & & & & \\
\hline
\end{tabular}

\section{Analysis of the Burnout Scale}

The factor analysis of the scale is implemented by using the table of varimax rotation for 21 items while excluding the fourth question with the results of reliability analysis. The results of the factor analysis show that the scale has five main factors. When the questions with total variance explained, less than $0.5(50 \%)$, of which 14, 19, and 11 are excluded during factor analysis, it is found that the scale has three main factors with the remaining 18 questions. The first factor which has a total variance explained of $74.8 \%$ is composed of six questions and eight statements representing "emotional exhaustion." The second factor which has a total variance explained of $87.3 \%$ is composed of five questions and six statements representing "personal accomplishment." Finally, the third factor which has a total variance explained of $61.8 \%$ is composed of five questions representing "depersonalization." (Table-3) 


\begin{tabular}{|c|c|c|c|}
\hline \multicolumn{4}{|c|}{ Table 3: The Factor Analysis Results of Burnout Scale } \\
\hline $\begin{array}{l}\text { KMO: } \mathbf{0 , 8 8 2} \\
\text { BTS: } 2780,48\end{array}$ & $\begin{array}{c}\text { Factor 1: Emotional } \\
\text { exhaustion (Total Vari- } \\
\text { ance Explained = 74.8) }\end{array}$ & $\begin{array}{c}\text { Factor 2: Personal } \\
\text { accomplishment (Total } \\
\text { Variance Explained = } \\
\mathbf{8 7 . 3 \%} \text { ) }\end{array}$ & $\begin{array}{l}\text { Factor 3: Depersonal- } \\
\text { ization (Total Variance } \\
\text { Explained }=61.8 \% \text { ) }\end{array}$ \\
\hline $\begin{array}{l}\text { Each day, I feel that I can't stand one more } \\
\text { day in this job. }\end{array}$ & 0.86 & & \\
\hline I feel that I am losing my desire for my job. & 0.82 & & \\
\hline I feel that I get bored of my job. & 0.77 & & \\
\hline $\begin{array}{l}\text { When I'm back home from work, I feel emo- } \\
\text { tionally exhausted. }\end{array}$ & 0.76 & & \\
\hline I feel that I came about to the end. & 0.69 & & \\
\hline I feel that my job limits me too much. & 0.59 & & \\
\hline $\begin{array}{l}\text { Working directly face to face with others } \\
\text { make me more stressed. }\end{array}$ & 0.73 & & \\
\hline $\begin{array}{l}\text { It's very corrosive for me to deal with the } \\
\text { other people. }\end{array}$ & 0.69 & & \\
\hline $\begin{array}{l}\text { I feel that I contribute to human beings by } \\
\text { means of my job. }\end{array}$ & & 0.68 & \\
\hline $\begin{array}{l}\text { I always find the best solutions for the people } \\
\text { with the requirements of my job. }\end{array}$ & & 0.66 & \\
\hline $\begin{array}{l}\text { I always create a good atmosphere with the } \\
\text { requirements of my job. }\end{array}$ & & 0.6 & \\
\hline I approach work problems calmly. & & 0.6 & \\
\hline $\begin{array}{l}\text { I have enough power to accomplish many } \\
\text { things. }\end{array}$ & & 0.59 & \\
\hline $\begin{array}{l}\text { I feel refreshed when I work closely with } \\
\text { others. }\end{array}$ & & 0.64 & \\
\hline $\begin{array}{l}\text { I feel like behaving to the others as if they are } \\
\text { animals with my job requirements. }\end{array}$ & & & 0.75 \\
\hline $\begin{array}{l}\text { I feel that people behave toward me as if I } \\
\text { have created problems to others as if they } \\
\text { are animals with the requirements of my job. }\end{array}$ & & & 0.65 \\
\hline $\begin{array}{l}\text { I became insensitive to others since I began to } \\
\text { this job. }\end{array}$ & & & 0.59 \\
\hline $\begin{array}{l}\text { I'm insensitive to the people I face with the } \\
\text { requirements of my job. }\end{array}$ & & & 0.58 \\
\hline
\end{tabular}

\section{The Reliability Analysis results of the Subfactors of Burn- out Measure}

The burnout measure was found to be composed of three sub-dimensions. The reliability analysis results of each sub-dimension are as follows: emotional exhaustion 0.87 ; reduced personnel accomplishment 0.76; and depersonalization 0.75 . With these results, the burnout measure can be considered as reliable within its sub-factors as well.(Table-4) 
Table 4: The Reliability Analysis Results of the Sub factors of Burnout Scale

\begin{tabular}{|l|l|}
\hline Sub factors of Burnout Scale & Reliability \\
\hline Factor 1: Emotional exhaustion & 0.87 \\
\hline Factor 2: Reduced personal accomplishment & 0.76 \\
\hline Factor 3: Depersonalization & 0.75 \\
\hline
\end{tabular}

\section{The Analysis of the Organizational Commitment Scale}

The factor analysis of the scale is implemented by using the table of varimax rotation for 16 statements while excluding two questions (13 and 14), which having total variance explained less than 0.5 . When the reliability analysis is implemented subsequently with the remaining 14 statements, it is found that the scale is composed of three factors. The first factor, which has a total variance explained of $84.9 \%$, is composed of six statements representing the "affective commitment." The second factor, which has a total variance explained of $93.6 \%$, is composed of five statements representing the "continuance commitment" sub-factor. Finally, the third factor, which has a total variance explained of $83.5 \%$, is composed of five statements representing "normative commitment" sub- factors. (Table-5)

\section{Table 5: The Factor Analysis Results of Organizational Commitment Scale}

\begin{tabular}{|c|c|c|c|}
\hline $\begin{array}{l}\text { KMO: } \mathbf{0 , 8 7 1} \\
\text { BTS: } 2759,540\end{array}$ & $\begin{array}{c}\text { Factor 1: Affective } \\
\text { Commitment (Total } \\
\text { Variance Explained = } \\
\text { 84.9\%) }\end{array}$ & $\begin{array}{l}\text { Factor 2: Continu- } \\
\text { ance Commitment } \\
\text { (Total Variance Ex- } \\
\text { plained }=\mathbf{9 3 . 6 \%} \text { ) }\end{array}$ & $\begin{array}{l}\text { Factor 3: Normative } \\
\text { Commitment (Total } \\
\text { Variance Explained = } \\
\mathbf{8 3 . 5 \% )}\end{array}$ \\
\hline $\begin{array}{l}\text { I feel a strong sense of belonging to my hospi- } \\
\text { tal. }\end{array}$ & 0.85 & & \\
\hline I feel emotionally attached to this hospital. & 0.83 & & \\
\hline I feel like part of the family at my hospital. & 0.80 & & \\
\hline $\begin{array}{l}\text { This hospital has a great deal of personal mean- } \\
\text { ing for me. }\end{array}$ & 0.78 & & \\
\hline $\begin{array}{l}\text { I really feel as if this hospital's problems are my } \\
\text { problems. }\end{array}$ & 0.76 & & \\
\hline $\begin{array}{l}\text { One of the major reasons I continue to work for } \\
\text { this hospital is that I believe that loyalty is im- } \\
\text { portant and therefore feel a sense of moral obli- } \\
\text { gation to remain. }\end{array}$ & 0.65 & & \\
\hline $\begin{array}{l}\text { Much of my life would be disrupted if I decided } \\
\text { I wanted to leave my hospital now. }\end{array}$ & & 0.80 & \\
\hline $\begin{array}{l}\text { I feel that I have too few options to consider } \\
\text { leaving this hospital }\end{array}$ & & 0.79 & \\
\hline $\begin{array}{l}\text { It would be hard for me to leave my hospital } \\
\text { right now, even I wanted to. }\end{array}$ & & 0.66 & \\
\hline $\begin{array}{l}\text { One of the few negative consequences of leav- } \\
\text { ing this hospital would } \\
\text { be the scarcity of available alternatives. }\end{array}$ & & 0.63 & \\
\hline $\begin{array}{l}\text { I wouldn't leave my hospital right now because I } \\
\text { have a sense of obligation to people. }\end{array}$ & & & 0.72 \\
\hline This hospital deserves my loyalty. & & & 0.70 \\
\hline I owe many things to my hospital. & & & 0.69 \\
\hline $\begin{array}{l}\text { I might not consider working elsewhere because } \\
\text { I have already put so much of myself into this } \\
\text { hospital }\end{array}$ & & & 0.53 \\
\hline
\end{tabular}




\section{The Analysis of the Relationships between Burnout and Organizational Commitment}

The relationships between burnout and organizational commitment will be analyzed in scope of the subscales. The reliability analysis results of the subfactors that are created with the results of factor analysis of Organizational Commitment Scale are listed in (Table 6).

The Regression Analysis of the Relationship between the "Emotional exhaustion" Sub factor of Burnout and Organizational Commitment

\begin{tabular}{|l|l|}
\hline \multicolumn{2}{|c|}{ Table 6: The Reliability Analysis Results of the Sub factors of Organizational } \\
Commitment Scale & Reliability \\
\hline Sub factors of Organizational Commitment Scale & 0.8939 \\
\hline Factor 1: Affective Commitment & 0.7202 \\
\hline Factor 2: Continuance Commitment & 0.7205 \\
\hline Factor 3: Normative Commitment & \\
\hline
\end{tabular}

The regression analysis reveals the results of the relationship between the "emotional exhaustion" subfactor of burnout and organizational commitment. "Emotional exhaustion" has a meaningful descriptive power on the "affective commitment" and "normative commitment" subfactors of organizational commitment. In that respect, the"emotional exhaustion" subfactor has a meaningful descriptive power on the "affective commitment" with a level of 53.3\%, which reveals a linear relationship between two variables, and the $53.3 \%$ variation of affective commitment is described by emotional exhaustion. In addition, the "emotional exhaustion" subfactor has a meaningful descriptive power on "normative commitment" with a level of $32.6 \%$ that reveals a linear relationship between two variables, and the $32.6 \%$ variation of normative commitment is described by emotional exhaustion. Finally, no relationship is found between emotional exhaustion and continuance commitment. (Table 7)

Table 7: The Results of the Regression Analysis of the Relationship between "Emotional Exhaustion" Sub factor of Burnout and Organizational Commitment

\begin{tabular}{|l|l|l|l|l|l|}
\hline & Adjusted $\mathrm{R}^{2}$ & $\mathrm{~F}$ & Stand.Beta Coef. & $\mathrm{t}$ & Signif.(p) \\
\hline Affective Commitment & 0.284 & 181.512 & $\mathbf{0 . 5 3 3}^{*}$ & 13.473 & $\mathbf{0 . 0 0}$ \\
\hline Continuance Commitment & 0.003 & 1.55 & -0.052 & -1.245 & 0.21 \\
\hline Normative Commitment & 0.106 & 54.354 & $\mathbf{0 . 3 2 6} * *$ & 7.372 & $\mathbf{0 . 0 0}$ \\
\hline
\end{tabular}

$* \mathrm{P}<0,05, * * \mathrm{p}<0,01$

Dependent Variable (Affective Commitment, Continuance Commitment, Normative Commitment) Independent Variable (Emotional exhaustion)

Regression Analysis of the Relationship between the "Reduced Personal Accomplishment" Sub factor of Burnout and Organizational Commitment

The results of regression analysis reveal the relationship between the "reduced personal accomplishment" subfactor of burnout and the organizational commitment. "Reduced personal accomplish- 
Journal of Global Strategic Management | V. 4 | N. 2 | 2010-December | isma.info | 137-149 | DOI: 10.20460/JGSM.2010415831 ment" subfactor is believed to have a meaningful descriptive power on the "affective commitment" and "normative commitment" of organizational commitment scale. In that respect, the "reduced personal accomplishment" subfactor has a meaningful descriptive power on the "affective commitment" with a level of $26.6 \%$, which reveals a linear relationship between two variables, and the $26.6 \%$ variation of affective commitment is described by emotional exhaustion. In addition, the "reduced personal accomplishment" subfactor has a meaningful descriptive power on "normative commitment" with a level of $-15.2 \%$, which reveals a negative relationship between two variables, and the $15.2 \%$ variation of continuance commitment is described by emotional exhaustion. Finally, no relationship is found between reduced personal accomplishment and normative commitment. (Table 8)

\begin{tabular}{|l|l|l|l|l|l|l|}
\hline $\begin{array}{l}\text { Table 8: The Results of the Regression Analysis of the Relationship between } \\
\text { 'Reduced Personal Accomplishment" Sub factor of Burnout and } \\
\text { Organizational Commitment }\end{array}$ \\
\hline Model & Adjusted $\mathrm{R}^{2}$ & $\mathrm{~F}$ & Stand.Beta Coef. & $\mathrm{t}$ & Signif.(p) \\
\hline Affective Commitment & 0.071 & 34.896 & $\mathbf{0 . 2 6 6} *$ & 5.907 & $\mathbf{0 . 0 0}$ \\
\hline Continuance Commitment & 0.023 & 10.872 & $\mathbf{- 0 . 1 5 2 *}$ & -3.297 & $\mathbf{0 . 0 0}$ \\
\hline Normative Commitment & 0.003 & 1.590 & 0.059 & 1.261 & 0.20 \\
\hline
\end{tabular}

$* \mathrm{P}<0.05$

Dependent Variable (Affective Commitment, Continuance Commitment, Normative Commitment)

Independent Variable (Personal Accomplishment)

\section{Regression Analysis of the Relationship between the "Desentization" Sub factor of Burnout and Organizational Commitment}

The results of regression analysis reveal the relationship between the "desentization" subfactor of burnout and organizational commitment. "Desentization" is believed to have a meaningful descriptive power on the "affective commitment" and "normative commitment" of organizational commitment scale. In that respect, the "desentization" subfactor has a meaningful descriptive power on the "affective commitment" with a level of $23 \%$, which reveals a positive linear relationship between two variables, and the $23 \%$ variation of affective commitment is described by emotional exhaustion. In addition to this, the "desentization" subfactor has a meaningful descriptive power on "normative commitment" with a level of $17.6 \%$, which reveals a positive relationship between two variables, and the $17.6 \%$ variation of normative commitment is described by emotional exhaustion. Finally, no relationship is found between desentization and continuance commitment. (Table 9)

Table 9: The Results of the Regression Analysis of the Relationship between "Desentization" Sub factor of Burnout and Organizational Commitment

\begin{tabular}{|l|l|l|l|l|l|}
\hline & Adjusted $\mathrm{R}^{2}$ & $\mathrm{~F}$ & Stand.Beta Coef. & $\mathrm{T}$ & Signif.(p) \\
\hline Affective Commitment & 0.053 & 25.6 & $\mathbf{0 . 2 3} * *$ & 5.060 & $\mathbf{0 . 0 0}$ \\
\hline Continuance Commitment & 0.001 & 0.581 & 0.036 & -3.297 & 0.44 \\
\hline Normative Commitment & 0.031 & 14.557 & $\mathbf{0 . 1 7 6}^{*}$ & 3.815 & 0.00 \\
\hline
\end{tabular}

$* \mathrm{P}<0.05, * * \mathrm{P}<0.01$

Dependent Variable (Affective Commitment, Continuance Commitment, Normative Commitment)

Independent Variable (Desentization) 


\section{DISCUSSION AND CONCLUSION}

One of the most important factors in today's business world is the human resources of organizations. It is not easy for top managements to make employees committed to their organizations, especially in the health sector, where much of the workforce use their own informational expertise in their daily activities. In that respect, organizational commitment is no doubt one of the most important factors to increase the added value of the personnel to the organization.

This study is performed to find out the relationship between the burnout and organizational commitment. When the structure of the study sample is considered, the majority of the sample includes mostly women, nurses, married, and university graduate personnel. The sample has an average age of 33 and a work experience of seven years.

This result reveals the difficulty of having committed personnel in the health sector, which includes such qualified personnel. The average work experience of this study is seven years, which is assumed to create one of the greatest reasons of having a high level of organizational commitment although having high scores on organizational burnout. In other words, it is believed that more work experience means more organizational commitment for the personnel. This result of the study is similar to another studies or researchs. Ceylan found a significant relationship between work experience and organizational commitment; the personnel having six years and more had a greater commitment than the personnel of one to five years.

Main factors that form burnout are listed as workload, insufficient personnel, and time pressures which are not easy to deal with in organizations. The necessities of face-to-face working with colleagues and patients, the emotional support that should be given to patients, and communication problems, affect health sector personnel negatively.

High expectations in the early times of work are believed to cause organizational burnout. Considering the average age of 33 in this study, it is an early period of work experience for the health sector employees.

Another study found that doctors experience burnout at a higher level than the others. In this study, the burnout mean scores of the doctors, considering subscales are 15.48 for emotional exhaustion, 5.51 for depersonalization, and 22.06 for personal accomplishment (Turkish Medical Association, 2005: 26). And, Özyurt's study on organizational burnout, doctors had scores of 13.4 for emotional exhaustion, 4.4 for depersonalization and 22.6 for personal accomplishment. The results of these two studies seem parallel. In other words, although the scores of personal accomplishment and burnout are high, their depersonalization scores seemed to be low. Thus, it is believed that although the doctors experience intensive organizational burnout, they were not senseless to their occupational necessities.

When the reduced personal accomplishment level increases (reduced personal accomplishment), affective commitment also increases. Especially in the times of crisis, emotional exhaustion seems to be affected negatively. But crisis environments force the unhappy personnel with a low level of organizational burnout to continue the status quo not to face a possible unemployment.

The results of this study indicate a relationship between burnout and the organizational commitment. There is a linear relationship between emotional exhaustion and affective and normative commitment. In that respect, while an increase or decrease in affective commitment level is described by emotional exhaustion with a 53\% percentage; also, a change in normative is described by emotional exhaustion with a $33 \%$ percentage.

This study also reveals that the factors of having positive expectations for the future and the idea that burnout would disappear in future, and also the great desire to climb the career steps affects the organizational commitment in a positive way for the personnel. In addition, it is found that a decrease in personal accomplishment causes an increase in continuance commitment. The people working for long periods in the same organizations may lose their self-trust, which subsequently bring the feeling to increase the continuance commitment level and stay in same organization to maintain the status quo. 
Another finding of this study is that when depersonalization increases affective commitment, normative commitment increases,too. Then, there is not a negative effect of depersonalization to the organizational commitment. In conclusion, although the personnel of medicine faculty hospital have depersonalization feelings, they keep their organizational commitments at high levels mainly because of their specific occupational characteristics.

In sum, this study revealed the relationship between burnout and organizational commitment. It is considered that quality issues, right service, efficiency, and effectiveness in the health sector make the issues of burnout and organizational commitment more important in today's organizational environment. In that respect, a future study is recommended to research these issues in another sector and groupings.

The results are consistent with the expectation that burnout leads to reduced organizational commitment. Although each of the three aspects of burnout were significantly correlated with organizational commitment, they did not all display a unique relationship with organizational commitment when entered into a multiple regression. The relationship between commitment and depersonalization appears to be redundant with that of the other two aspects of burnout. It may be, as suggested earlier, that the role of depersonalization is in mediating the development of reduced personal accomplishment, and thus it does not have an independent contribution to make to the level of commitment.

This study had several limitations. First, both samples were taken from the same hospital setting. Although this strengthens the comparative aspect of the design by ruling out organizational goals, structure, and other potential confounds, it also restricts the generalizability of these results. Second, the present analyses excluded other potential mediators of burnout, such as supervisory support, coworker support, job satisfaction, etc. Third, more integrated investigations of these two issues are warranted and further systematic research is needed to explore the dynamics of the interaction between these important constructs among various occupational groups. Even though this study has several limitations, it sheds a light to future research efforts. In the future conducting studies with larger sample sets will contribute to the literature. Especially including organizational behaviour matters -that may affect organizational commitment and burn out to the study may result in more effective results. 


\section{REFERENCES}

Allen, N.J.; J. P. Meyer (1990). The Measurement and Antecedents of Affective, Continuance and Normative Commitment to the Organization, Journal of Occupational Psychology, 63(1), 1-18.

Aras, Z. (2006). Birinci Basamak Sağlık Kurumlarında Çalışan Hemşire ve Ebelerin Tükenmişlik Durumlarl, [The Burnout Levels of Nurses and Midviwes], Marmara University Master's Thesis, İstanbul.

Ceylan, O. (2002). Ödül Yönetiminin Çalışanlarda İş Tatmini ve Örgütsel Bağlllık Yaratmadaki Rolü ve Bir Uygulama, [The Effect of Reward Management on Job Satisfacition and Organizational Commitments of the Employees], Marmara University Master's Thesis, Istanbul.

Ciper, A. (2006). Tükenmişlik Sendromunun Hizmet Kalitesine Etkisi ve Çağrı Merkezlerinde Uygulamast, [The Effect of Burnout Syndrome to Service Quality: A Study in Call Centers], Marmara University Master's Thesis, Istanbul.

Eren, E: Örgütsel Davranış ve Yönetim Psikolojisi, Beta Yayınları,2008 İstanbul.

Jackson, S.E.; Schwab, R.L. and Schuler, R.S. (1986). Toward an Understanding of the Burnout Phenomenon, Journal of Applied Psychology, Vol. 71, No.4, 630-40.

Maslach, C.; Jackson, S.E. (1981). The Measurment of Experienced Burnout, Journal of Occupational Behavior, Vol:2

Maslach C.; Jackson S.E. (1986). MBI: Maslach Burnout Inventory. Manual Research Edition. Palo Alto, CA, USA: University of California, Consulting Psychologists Pres.

Maslach C.; Jackson S.E. and Leiter M.P. (1996): Maslach Burnout Inventory. Manual 3rd Edition. Palo Alto, CA, USA: University of California, Consulting Psychologists Pres.

Maslach, C.; Jackson, S. E. (1984). Burnout in Organizational Settings, Applied Social Psychology Annual, 5, 133-153.

Maslach C.; Schaufeli WB. and Leiter MP. (2001). Job Burnout, Annual Review Psychology, 52, 397 -422 .

Meyer, J. P.; N. J. Allen (1991). A Three-component Conceptualization of Organizational Commitment, Human Resource Management Review, 1(1), 61-89.

Mowday, R. T.; Steers, R. M. and Porter, L. W. (1979). The Measurement of Organizational Commitment, Journal of Vocational Behavior, 14, 224-247.

Morris, J. H.; Sherman, J.D. (1981). Generalizability of an Organizational Commitment Model, Academy of Management Journal, 24, 512-526.

Ozyurt, Ali (2003): İstanbul Hekimlerinin Işs Doyumu ve Tükenmişlik Düzeyleri, [The Job Satisfaction and Burnout Levels of Doctors in Istanbul], Marmara University Doctoral Thesis, Istanbul.

Sarikaya, P.. (2007). Tükenmişlik Sendromunda Kişilik Özelliklerinden Denetim Odă̆l İle İliş̧isi ve Bir Uygulama, [The relationship between Job Satisfaction and Burnout], Marmara University Master's Thesis, İstanbul.

Shimizu T.; Mizoue T.; Kubota S.; Mishima N. and Nagata S. (2003): Relationship Between Burnout and Communication Skill Training Among Japanese Hospital Nurses: A Pilot Study, Journal of Occupational Health, 45, 185-190.

Sucuoglu B, Kuloglu N. (1996). “Özürlü Çocuklarla Çalışan Öğretmenlerde Tükenmişliğin Değerlendirilmesi, [The Evaluation of Burnout levels of Teachers Working with Disables], Turkish Journal of Psychology, Vol:10, 44-60. 
Sunter A.T.; Canbaz S.; Dabak S.; Oz H, Peksen Y. (2006). Pratisyen Hekimlerde Tükenmişlik, İşe Bağlı Gerginlik ve İş Doyumu Düzeyleri, [The Burnout, Work Tension and Job Satisfaction Levels of Practitioner Doctors], The Journal of General Medicine, 16 (1).

Steers, R. M. (1977). Antecedents and Outcomes of Organizational Commitment, Administrative Science Quarterly, 22, 46-56.

Turkish Medical Association (2005). Türkiye'de Tabip Odalarına Kayıtlı Olan Bir Grup Hekimde Tükenmişlik Sendromu ve Etkileyen Faktörler, [The Burnout Syndrome and It's Causes of Doctors registered to Turkish Medical Association], Ankara.

Turker, M. (2006). Çalışanların Rol Tanımlamalarinin Örgütsel Vatandaşlık Davranışlarına Etkisi, [The Effect of Role Definitions of Employees to the Organizational Citizenship Behavior], Marmara University Master's Thesis, Istanbul. 